\title{
Alternative construction and demolition (C\&D) waste characterization method proposal
}

\author{
Proposta de método alternativo para identificação \\ da composição de resíduos de construção civil (RCC)
Rodrigo Eduardo Córdoba** $\odot$, José da Costa Marques Neto' $\odot$, Cristine Diniz Santiago' ${ }^{\oplus}$, Erica Pugliesi' $\odot$, Valdir Schalch ${ }^{2} \odot$

\section{ABSTRACT}

Construction and demolition waste generally represents the majority of solid waste generated in Brazilian cities, and characterization of this waste stream is still incipient. Therefore, to support managers in the process in the diagnostic phase, this study consisted in a proposal qualitative characterization method in field, that use of construction and demolition (C\&D) waste generation indicators. For this, a survey which have been divided in two stages: quantitative characterization based on a three-indicator-analysis of C\&D waste generation and qualitative characterization consists of an image analysis procedure on C\&D waste samples. The qualitative characterization method has proved to be efficient for samples with high-volume parts. However, this method is limited to represent characterizations that contain residues which might cover the other $C \& D$ waste types, for example, plastic sheeting, cardboard and packaging. This method of image analysis is suitable for use in early diagnostics, which require fast results about C\&D waste composition.

Keywords: construction and demolition waste; waste management; built environment; civil construction; characterization methods.

\section{RESUMO}

Os resíduos da construção civil podem representar a maior parte dos resíduos sólidos gerados nos municípios, e o conhecimento de sua composição ainda é limitado. Para apoiar gestores na fase de diagnóstico desses resíduos, este estudo propõe um método de campo que forneça a sua caracterização qualitativa apoiado em indicadores de geração. Para tanto, a pesquisa fo dividida em duas etapas: caracterização quantitativa baseada na análise de três indicadores de geração de resíduos da construção civil; e caracterização qualitativa, que consistiu em um procedimento de análise de imagem de amostras de resíduos da construção civil. O método de caracterização qualitativa provou ser eficiente para amostras volumosas. No entanto, esse método foi considerado limitado para representar caracterizações que contêm resíduos que podem abranger outros tipos de resíduos de construção civil, a exemplo de plásticos, papelão e embalagens. O método de análise de imagem mostrou-se adequado para uso em diagnósticos preliminares, os quais exigem resultados rápidos sobre a composição dos resíduos da construção civil.

Palavras-chave: resíduos de construção civil; ambiente construído; construção civil; métodos de caracterização.

\section{INTRODUCTION}

Waste diversity and generation has increased along with the intensification of the urbanization process (MESJASZ-LECH, 2014; SENG et al., 2010). Waste management has been placed by Hoornweg \& Bhada-Tata (2012) as one of the most relevant issues of urban management, since it is one of the most important urban lifestyle by-products, growing more than the world urbanization rate itself.

In this scenario, waste diversity generates waste streams, such as Construction and Demolition Waste (C\&D), which increases the complexity of its management and demands efforts from the public and private sector to deal with this matter (ZAMBRANA-VASQUEZ et al., 2016). The complexity of waste management does not dimish the urgency of adequate solutions.

$\mathrm{C} \& \mathrm{D}$ waste generation increased in Brazil over the past years due to a favorable economic performance, in which the construction industry more than quadruplicated its participation on the country's gross domestic product (GDP) (THE WORLD BANK, 2016; IBGE, 2014; CBIC, 2016). Among several waste streams, it is logical to say that $\mathrm{C} \& \mathrm{D}$ waste is an important part of this matter, since it generally represents the majority of solid waste generated in Brazilian urban areas. The mass of C\&D waste may represent two or three parts of the total solid waste in small and medium municipalities.

口

Universidade Federal de São Carlos - São Carlos (SP), Brazil

¿Universidade de São Paulo - São Paulo (SP), Brazil.

*Corresponding author: cordoba@ufscar.br

Received: 05/09/2017 - Accepted: 12/04/2017 - Reg. ABES: 179720 
Great $\mathrm{C} \& \mathrm{D}$ waste generation associated with abscence or shortcoming of management systems contribute to illegal disposal in the country. For example, the International Solid Waste Association (ISWA) representative in Brazil states that, in 2014, 45 milion C\&D waste tons were collected by the municipalities, including $C \& D$ waste generated by the municipalities and illegally discarded C\&D waste (ABRELPE, 2015). Considering official data, C\&D waste in Brazil represented $30.39 \%$ of the total waste collected by the municipalities in 2014 (SNIS, 2014).

$C \& D$ waste generation is also significant in emerging-market countries. In China, for instance, it is estimated that about 1.13 billion C\&D waste tons were generated in 2014, even with the decay of civil construction activities since early 2010 (LU et al., 2017). In Portugal and Spain, the generation was of 11 and 30 million C\&D waste tons in 2009 (BIO INTELLIGENCE SERVICE, 2011).

In 2010, a study mapped the waste generation activities of the European community, finding that civil construction activities are their largest generators, with $33.3 \%$ of the waste (EUROSTAT, 2010). Also, the study revealed that, in 2011, the average generation of C\&D waste was 700 million tons. If the excavated soil was included, this value would grow significantly, to about 1,350 to 2,900 million tons/year (BIO INTELLIGENCE SERVICE, 2011). In the US, the United States Environmental Protection Agency (USEPA) presented on its 'Advancing Sustainable Materials Management' report that, in 2013, the US generated about 530 million C\&D waste tons (USEPA, 2013).

Brazil has to deal with tons of C\&D waste which are disposed in illegal discharges dumping sites, unapproved areas, vacant lots and permanent preservation areas. The accumulation of this waste causes negative impacts, such as visual pollution, obstruction of urban drainage systems, proliferation of poisonous animals and disease vectors (IPEA, 2012; CÓRDOBA, 2014).

The absence of public policies regarding the management of such waste stream causes negative impacts such as illegal discharges on dumping sites, in areas far from the urban perimeter, and increased costs generated by public cleaning services, which get overcharged. However, public efforts without proper regulation and planning have proved to be ineffective to minimize the negative impacts caused by the irregular C\&D waste disposal (CÓRDOBA, 2014; DING; WANG; ZOU, 2016).

Brazilian resolution No. 307/2002 of the National Environmental Council deals specifically with C\&D waste, and it is still very present as a technical regulation guide for this waste stream. This resolution establishes that municipalities must provide public policies aiming at preventing irregular disposal of $C \& D$ waste, and reducing negative impacts to the environment and human health (BRASIL, 2002).

Despite regulation, a number of municipalities use inappropriate management procedures. In a universe of 5,564 Brazilian municipalities, only 4,031 have a C\&D waste management system. Some municipalities still have C\&D waste irregular disposal sites, like sanitary landfills and illegal discharges dumping locations (IBGE, 2008).

In Brazil, the increased generation of solid waste has led authorities, researchers and the society to direct their efforts towards waste handling and final disposal in a reactive posture (JACOBI \& BESEN, 2011). It is imperative to stress the Brazilian government delay to establish clear rules in a national waste law, which only happened in 2010, when the National Waste Policy was approved and regulated by National Decree 7,404/2010. Until then, the country had several technical regulations, which interfered in integrated waste management (ARAÚJO, 2013; GODOY, 2013).

As the major waste law in Brazil, The National Waste Policy defines C\&D waste as the one generated by constructions, rebuildings, repairs and demolitions, including those resulted from ground preparation and digging for building. Also, the Policy defines that this type of waste is their generator's responsibility (BRASIL, 2010).

However, there is limited knowledge on the generated amounts of waste and the composition and dangerousness of these materials, as well as on the possible risks of their disposal in the ground. These possible hazards can be exarcebated by irregular C\&D waste disposal, without mitigation measures like leachate drains. In this context, C\&D waste leachate may be leached to water supplies, causing risks to both human health and the environment (FERGUSON \& MALE, 1980; TOWNSEND; JANG; THURN, 1999; ROUSSAT et al., 2008; CÓRDOBA, 2014).

Several authors report that the disposal of small quantities of hazardous waste and other types of waste can occur in C\&D waste landfills, enabling soil and water contamination (FERGUSON \& MALE, 1980; TOWNSEND; JANG; THURN, 1999; ANGULO \& JOHN, 2006).

Studies on the C\&D waste field have been increasing, but the complexity of its management in terms of volume, weight and dimensions stress the need to propose new methods for C\&D waste diagnosis and characterization.

Previous studies about generation estimates and characterization focus solely on collecting the generating source's data, e.g. in residential and non-residential construction sites (KATZ; BAUM, 2011; SÁEZ \& MERINO, 2011; LLATAS, 2011).

In Brazil, great differences among diagnosis data regarding $C \& D$ waste highlight the scarcity of reliable data in the country, reinforcing the need for improving methods and analyzing existing regulations (ABRELPE, 2015). In this sense, Brazilian Institute of Applied Economic Research (IPEA) identified a diversity of in-field C\&D waste characterization methods, once it is not possible to control nor standardize C\&D waste characterization and generation methods (IPEA, 2012).

Castro et al. (1997) performed in-field C\&D waste characterizations based on similar household waste characterization methods, 
developed based on the technique of separating the samples in $1 / 4$ portions or "quarteamento", brought by NBR 10.007/2004 - Solid Waste Sampling.

However, this method, inspite of being based on normative techniques, shows limitations when applied to $C \& D$ waste due to mass and volume specificities of this type of waste, besides consuming time and economic resources to rent heavy machinery - such as tractors and backhoes - and workers with specific training for $\mathrm{C} \& \mathrm{D}$ waste separation.

Therefore, it is important to identify alternative methods for quantitative and qualitative $\mathrm{C} \& \mathrm{D}$ waste characterization, in order to understand soil disposal hazards, creating an appropriate C\&D waste management, in accordance with the National Policy and resolution No. 307/2002 (BRASIL, 2002).

Thus, this paper aims at contributing with an alternative C\&D waste qualitative characterization method, which also takes quantitative aspects into account. This new method may offer new possibilities to analyse C\&D waste composition at in-field researches, helping upcome existing obstacles which can hinder the work of managers using traditional methods.

\section{LITERATURE REVIEW}

\section{Fundamentals of $C \& D$ waste management in Brazil}

The National Waste Policy - previously quoted law 12,305/2010 established principles, objectives, instruments and orientation for integrated solid waste management. In this sense, C\&D waste management must follow the National Policy guidance. Similar waste policy from the European Community - Directive 2008/98/UE — defines the primary focus of the Waste Policy as not generating waste and then reducing, reusing, recycling, recovering energy, treating and adequately disposing refuses.

According to the Brazilian National Waste Policy, national resolution No. 307/2002 was complemented by national resolution No. $448 / 2012$, laying emphasis on orientations, criteria and procedures for $\mathrm{C} \& \mathrm{D}$ waste management. The main orientations are: $\mathrm{C} \& \mathrm{D}$ waste generators are responsible for appropriate destination and disposal; C\&D waste must not be disposed in sanitary landfills and illegal discharges dumping sites; Municipal Management Plans for C\&D waste must be formulated; and C\&D waste must be separated according to their class for reuse, recycling, energy recovery, treatment and final disposal, observing this hierarchy.

In Brazil, the municipalities prepare their Municipal Management Plans of Solid Wastes following the orientations of the National Waste Policy. These plans must have incorporated the Municipal Management Plan for C\&D wastes.
Figure 1 presents a flowchart with the basic management streams according to the resolution. These plans must contain a C\&D waste Municipal Management Plan, as well as Management Specific Plans.

Municipal Management Plans for C\&D waste have a wide range of information, since they aim at stablishing criteria for generator's responsibilities, oversighting, as well as registration of $\mathrm{C} \& \mathrm{D}$ waste handling areas. The C\&D waste Municipal Management Program is directed also at minor generators (generation of up to 1 or $2 \mathrm{~m}^{3}$ per day) and it must create orientations to carry out generators' responsibilities. In this sense, the program aims at contributing to the implantation of delivery points for small C\&D waste volumes, preventing their disposal in illegal discharges dumping sites. For adequate C\&D waste management in construction sites, resolution No. 307/2002 stresses the need of Specific Plans for C\&D waste management.

Many countries use codes or classes to identify C\&D waste in order to standardize the language used for information, monitoring, controling, oversighting and management's efficiency assessment in different scales.

The National Waste Policy defines C\&D waste but does not divide classes to categorize it, since this is a technical assignment. Therefore, in 2012, the Brazilian Institute of Environment and Renewable Natural Resources (IBAMA) published the Normative Instruction No. 13, instituting the Brazilian Waste List, based on the same classifying structure (chapters, subchapters and codes) as the European Waste Catalogue (Commission Decision 2000/532/EC). A number of studies (Villoria-SÁEZ \& Del Río MERINO, 2010; Villoria-SAÉZ; MERINO; PORRAS-AMORES, 2011) determined the amount of waste per type according to the European Waste Catalogue.

In Brazil, the list is still underused for C\&D waste management, because national resolution No. 307/2002 presents only four classes which cover the list. These classes were modified throughout the years by complementary resolutions - resolutions No. 348/2004, 431/2011, 448/2012 and 469/2015. Resolution No. 307/2002 technically classifies C\&D waste in:

- Class A - reusable or recyclable waste as aggregates, such as ceramic components (bricks, blocks), grout and concrete;

- Class B - recyclable waste for other destinations, such as plastics, metals, wood and gypsum;

- Class C - waste without economically viable technologies or applications for recycling or recovery;

- Class D - hazardous waste, such as paints, oils and asbestos.

This classification aims at facilitating the final destination of C\&D waste to recycling plants (C\&D waste plants) and final disposal landfills. Potential recycling C\&D waste are the class $\mathrm{A}$ - recyclable in $\mathrm{C} \& \mathrm{D}$ waste plants - , and class B - recyclable waste for other destinations as household waste recycling plants - ones. 


\section{Quantitative and qualitative characterization}

In Brazil, C\&D waste is defined by the National Waste Policy (BRASIL, 2010) and resolution No. 307/2002 as: wastes generated by constructions, renovations, repairs and demolition of construction works, including those from the preparation and excavation of land. In this context, it is correct to say that the C\&D waste are material debris from construction sites, planned demolitions and natural disasters demolition.

Estimates of the C\&D waste amount in construction sites have been made by several authors, who used methods based on the formulation of generation indicators (PINTO, 1989; MAÑ̃̀ I REIXACH et al., 2000; CARNEIRO, 2005; TAM et al., 2008; KOFOWOROLA \& Gheewala, 2009; SOLÍS-GUZMÁN et al., 2009; KATZ \& BAUM, 2011;
Villoria SÁEZ \& Del Río MERINO, 2010; LLATAS, 2011). These indicators seek to relate the generated waste amount and the total amount of acquired waste in percentage, or yet to relate the mass or volume of generated waste with the built area.

In Spain, C\&D waste generation by built area in residential areas varied from 0.0746 to $0.1388 \mathrm{~m}^{3} / \mathrm{m}^{2}$ (MAÑÀ I REIXACH et al., 2000; LLATAS, 2011; Villoria SAÉZ; Del Río MERINO \& PORRAS-AMORES, 2011), but in Brazil this index can vary from 62.31 to $150 \mathrm{~kg} / \mathrm{m}^{2}$, representing from 0.0519 to $0.125 \mathrm{~m}^{3} / \mathrm{m}^{2}$ (tax converted based on C\&D waste $1,200 \mathrm{~kg} / \mathrm{m}^{3}$ unit mass) (PINTO, 1999; MARQUES NETO, 2005; COSTA, 2012). These wastage values are still valid in the country, since Brazilian construction sites are still based on the wastage logic (MARQUES NETO, 2009).

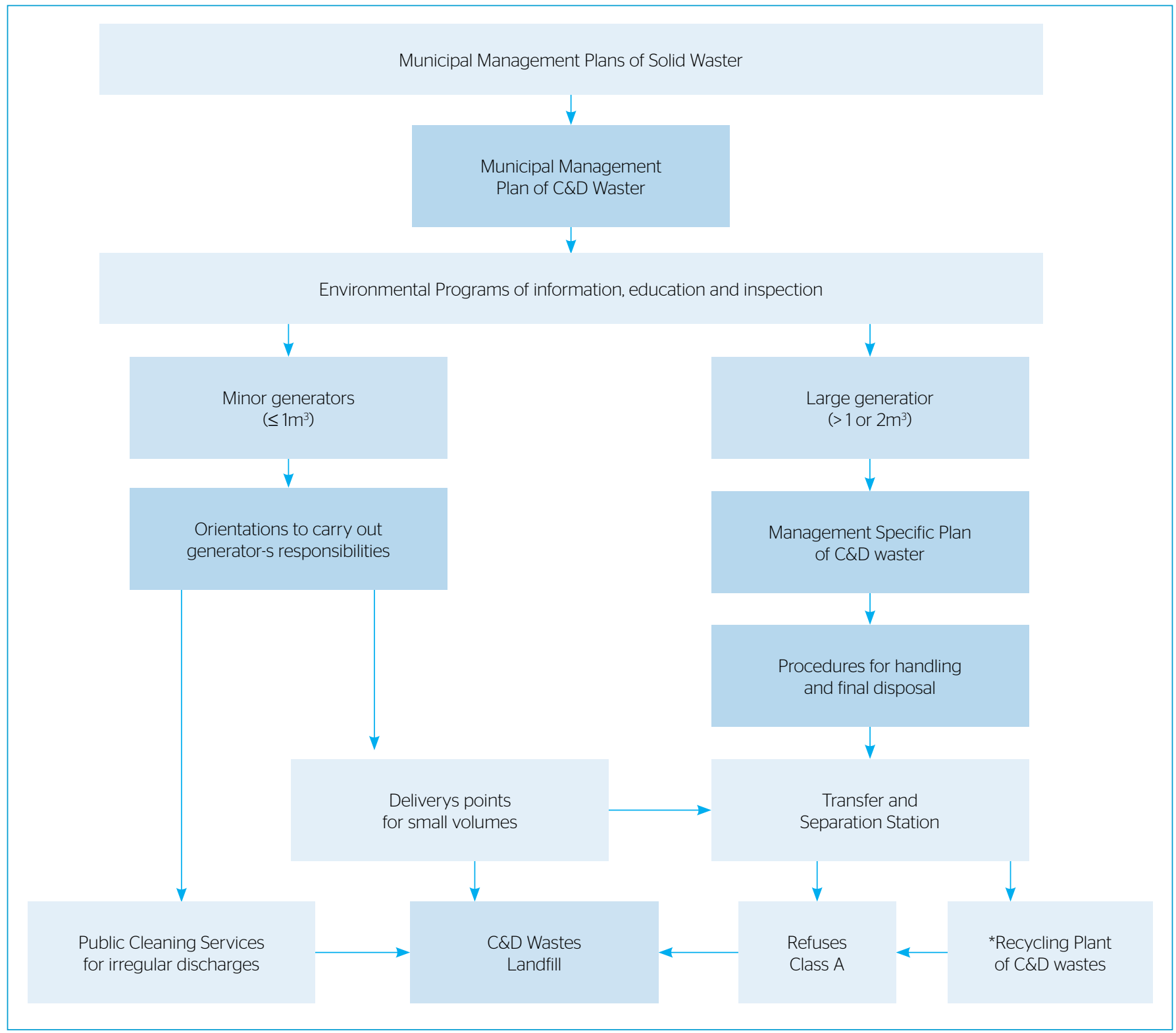

Figure 1 - Construction and demolition (C\&D) waste management in Brazilian municipalities flowchart. 
Pinto (1999) proposed an estimate method for urban C\&D waste generation, based on three indicators. These indicators are obtained through three databases: approved construction areas; the cargo transported by collectors, and monitoring of the final destination. These indexes allowed estimating a per capita generation from 1 to $3 \mathrm{~kg} /$ inhab.day (MARQUES NETO, 2005).

In terms of composition, $\mathrm{C} \& \mathrm{D}$ waste is composed by materials such as: ceramic components (bricks, blocks, tiles), concrete, soils, stones, metals, resins, glues, paints, wood, grout, gypsum, asphalt, glasses, plastics, pipes, electrical wiring and others (BRASIL, 2002).

The knowledge of waste amounts and composing materials are key factors to implement management plans. However, the plan's content is still limited to C\&D waste generation amount estimates (Villoria-SAÉZ; Del Río MERINO \& PORRAS-AMORES, 2011). Municipal managers and builders claim that this limitation is due to difficulties found in the application of qualitative characterization procedures. These professionals face difficulties handling C\&D waste in two aspects of characterization - time and manual screening due to its high mass and volume. Some studies determined C\&D waste per type of material, but these studies were developed in construction sites with reduced samples of C\&D waste (KATZ \& BAUM, 2011; LLATAS, 2011).

In the urban sphere, qualitative characterization is complex, since samples can come to the order of 100 to 400 tons. Castro et al. (1997) sampled 400 ton, reducing it to an amount of 5 ton, which was manually screened. Other authors such as Pinto (1989) or Marques Neto (2005) collected punctual C\&D waste samples in waste disposal areas, which together surpassed $300 \mathrm{~kg}$. The methods used by Pinto (1989) and Marques Neto (2005) revealed difficulties to collect volumous pieces such as beams, large concrete blocks and wooden planks.
Table 1 shows C\&D waste physical characterization results by Castro et al. (1997), Pinto (1989), Marques Neto (2005) and Lima \& Cabral (2013). Pinto (1989) observed that concrete and grout are first in percent per weight with $68.7 \%$ and ceramic compounds are in second with 29\%. Castro et al. (1997) related that sand, soil and stone are first in percent per weight with $82.5 \%$, concrete and grout in second with $11.4 \%$, and ceramic compounds in third with $2.5 \%$. Marques Neto (2005) estimated that ceramic compounds are first in percent per weight with $40.5 \%$, concrete and grout in second with $27.0 \%$, and sand, soil and stone in third with $19.4 \%$. A study following a method analogous to Marques Neto's (2005) identifyied that concrete and grout may represent $37.6 \%$, followed by ceramic components $(31.1 \%)$ and soil and sand (24.6\%). Carmo, Maia and César (2012) also identified predominance of ceramic components and concrete in their study, corroborating the results of the presented characterizations. The estimated data indicates that between 87 and $99 \%$ of the generated C\&D waste can be classified as "Class A" waste, therefore recyclable in C\&D waste plants.

Carmo, Maia and César (2012) report that some external factors may contribute to a great variability of C\&D waste and as a consequence may also affect the quality of recycled aggregates made from these materials. From the external factors reported by the authors, the origin can also be considered relevant, since authors considered C\&D waste originated from new constructions, demolition, renovations, gross land (including excavations and ground clearance), mixed $\mathrm{C} \& \mathrm{D}$ waste (made of C\&D waste originated from diverse sources), and $\mathrm{C} \& \mathrm{D}$ waste originated from the cleaning of clandestine discard areas.

Looking at the difficulties found in the characterization methods from literature and the importance of acknowledging C\&D waste origin, we highlight the importance of new methods that, at the same

Table 1 - Composition per weight of construction and demolition (C\&D) waste in characterization studies.

\begin{tabular}{|c|c|c|c|c|c|}
\hline Component & $\begin{array}{c}\text { Recyclable } \\
\text { in C\&D waste plants }\end{array}$ & $\begin{array}{l}\text { Percentage per weight } \\
\text { (São Carlos-SP - 1989)' } \\
(\%)\end{array}$ & $\begin{array}{l}\text { Percentage per weight } \\
\text { (São Paulo-SP-1997)² } \\
\text { (\%) }\end{array}$ & $\begin{array}{l}\text { Percentage per weight } \\
\text { (São Carlos-SP-2003) } \\
\text { (\%) }\end{array}$ & $\begin{array}{l}\text { Percentage per weight } \\
\text { (Fortaleza CE-2013) } \\
\text { (\%) }\end{array}$ \\
\hline Sand/Soil/Stone & recyclable & 1.51 & 82.54 & 19.48 & 24.6 \\
\hline Concrete/ Grout & recyclable & 68.71 & 11.69 & 27.09 & 37.6 \\
\hline Ceramic Components & recyclable & 29.09 & 2.57 & 40.57 & 31.1 \\
\hline Finishing Materials & non recyclable & 0,20 & 1.01 & 0.62 & 0.2 \\
\hline Wood & non recyclable & 0.11 & 0.85 & 7.05 & \multirow[b]{2}{*}{1.4} \\
\hline $\begin{array}{l}\text { Paper / Cardboard / } \\
\text { Plastic }\end{array}$ & non recyclable & - & 0.33 & 1.00 & \\
\hline Asphalt & non recyclable & - & 0.29 & - & - \\
\hline Metal & non recyclable & - & 0.28 & 1.56 & - \\
\hline Asbestos & non recyclable & 0,38 & - & 1.94 & - \\
\hline Gypsum & non recyclable & - & - & 0.69 & 5,0 \\
\hline Totals & - & 100.00 & 100.00 & 100.00 & 100.00 \\
\hline
\end{tabular}

Source: Pinto (1989); ${ }^{2}$ Castro et al. (1997); ${ }^{3}$ Marques Neto (2003), Lima \& Cabral (2013), adapted by the authors. 
time, help fasten the charactherization methods and contemplate the origin of this type of waste.

\section{METHODOLOGY}

The present study was conducted in São Carlos, a medium-sized city located in the east-center of the state of São Paulo, southeast of Brazil (Figure 2). The city had 221,950 inhabbitants according to the last census and a demographic density of $195.15 \mathrm{inhab} / \mathrm{km}^{2}$, in a $1,137.332 \mathrm{~km}^{2}$ area (IBGE, 2010). São Carlos is located at about $230 \mathrm{~km}$ of the state's capital, São Paulo.

Some Brazilian municipalities, including São Carlos, have already prepared integrated C\&D waste management plans. These municipalities prepared their plans based on orientation by resolution No. 307/2002.

The following subsections present this paper's detailed methods, which have been divided in two stages: quantitative and qualitative characterization.

\section{First Stage: Quantitative characterization}

For the quantitative characterization, the method from the study of Pinto (1999) was used. It is based on a three-indicator-analysis of C\&D waste generation, detailed below:
- First indicator $\left(i_{1}\right)$ : Production in approved constructions: estimated C\&D waste generation in the municipality, based on the area in square meters $\left(\mathrm{m}^{2}\right)$ of new constructions and renovation projects approved by the city hall, converted to mass through the local generation rate, which is $137.02 \mathrm{~kg} / \mathrm{m}^{2}$ (MARQUES NETO, 2005). Equation 1 presents the method to obtain the first indicator.

$i_{1}=\frac{\sum A \cdot B_{r}}{1000 \cdot t \cdot m_{u}}$

$\mathrm{i}_{1}\left(\mathrm{~m}^{3} / \mathrm{dia}\right)=$ first indicator;

$\mathrm{A}\left(\mathrm{m}^{2}\right)=$ approved construction areas;

$\mathrm{B}_{\mathrm{r}}\left(\mathrm{kg} / \mathrm{m}^{2}\right)=$ bulk rate of C\&D $137.02 \mathrm{~kg} / \mathrm{m}^{2}$;

$\mathrm{t}$ (days) $=$ days of generation in the year -288 days of generation, excluding Sunday;

$\mathrm{m}_{\mathrm{u}}\left(\mathrm{t} / \mathrm{m}^{3}\right)=$ unit mass $-0,6$ a $1,2 \mathrm{t} / \mathrm{m}^{3}$.

- Second indicator $\left(\mathrm{i}_{2}\right)$ : Cargo transported by collectors: estimated C\&D waste generation based on the information of the collection company. In order to estimate small-volume generators C\&D waste generation, the amounts of this waste collected in illegal

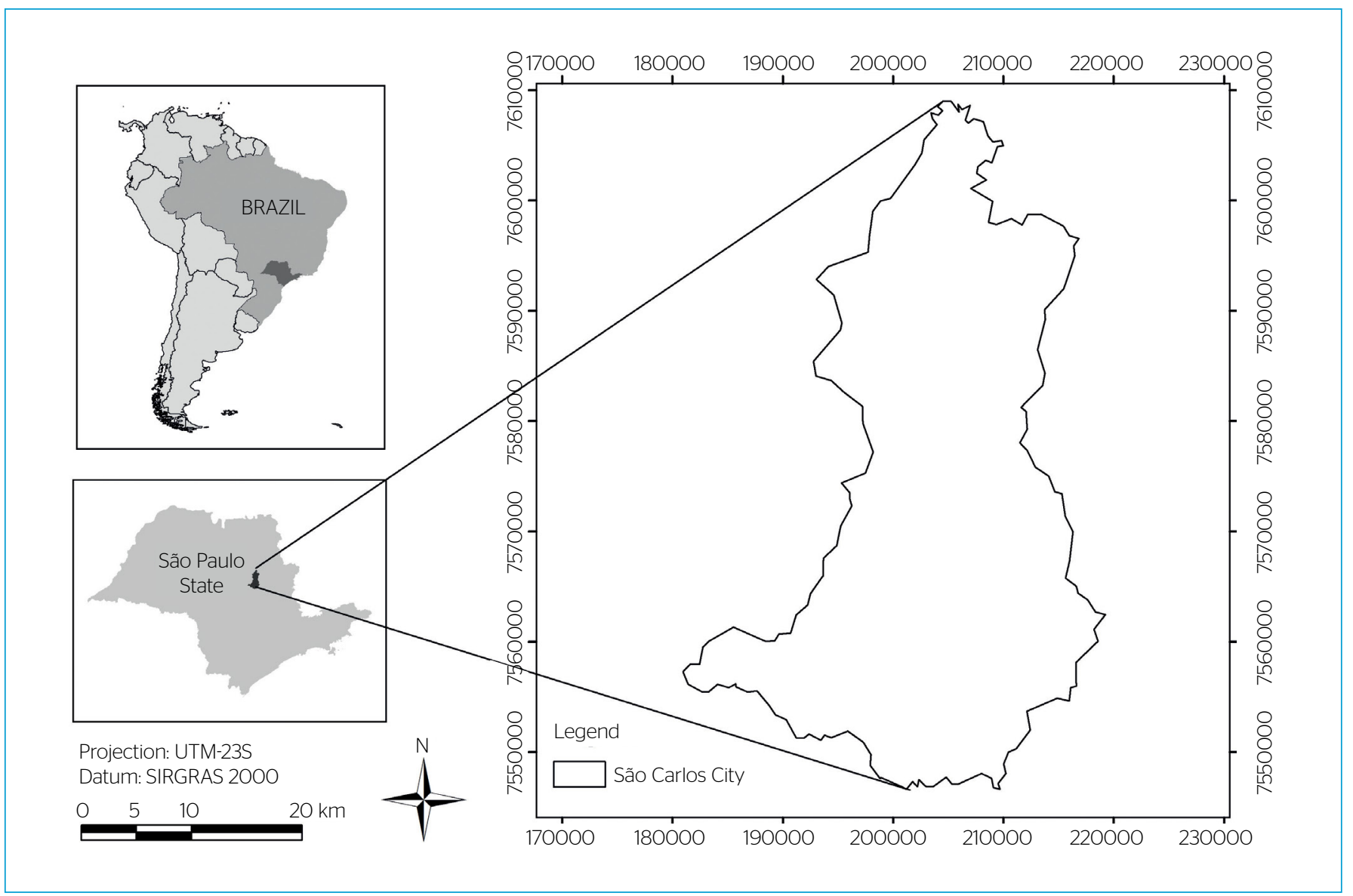

Figure 2 - São Carlos City location. 
dumping sites and the amount delivered to voluntary deliver locations were used. These values were obtained by receipt control at final disposal areas. Equation 2 presents the method to obtain the second indicator.

$i_{2}=\frac{\Sigma V_{c}}{t}$

$\mathrm{i}_{2}\left(\mathrm{~m}^{3} / \mathrm{dia}\right)=$ second indicator;

$\mathrm{V}_{\mathrm{c}}\left(\mathrm{m}^{3}\right)=$ bulk transported by collectors;

$\mathrm{t}$ (days) $=$ days of generation in the year -288 days of generation, excluding Sunday.

- Third indicator $\left(i_{3}\right)$ : Tracking and receipt control of waste transportation in disposal areas: estimation of $\mathrm{C} \& \mathrm{D}$ waste generation by discard control in the recycling plant, transfer and separation station, or in the $C \& D$ waste landfill. Equation 3 presents the method to obtain the third indicator.

$i_{3}=\frac{\Sigma V_{d}}{t}$

$\mathrm{i}_{3}\left(\mathrm{~m}^{3} / \mathrm{dia}\right)$ : third indicator;

$\mathrm{V}_{\mathrm{d}}\left(\mathrm{m}^{3}\right)$ : quatity disposal;

$t$ (days): days of generation in the year -288 days of generation, excluding Sunday.

\section{Second Stage: Qualitative characterization}

This paper proposes a new qualitative characterization method, which uses C\&D waste generation indicators to subsidize characterization methods results. The method consists in mixing two qualitative methods from the weighted quantitative characteristics of the sampling site. The first qualitative method, also used by Marques Neto (2003), physically collected punctual C\&D waste samples. The second consists of an image analysis procedure on C\&D waste samples.

In the first method, wastes samples were collected in disposal areas. In Sao Carlos, there were only two final destination areas recycling plant and C\&D waste landfill. A total of $864 \mathrm{~L}$ samples were collected in these areas. The samples' components were separated manually.

The first method is non-probabilistic for qualitative characterization. It consists on the selection of samples based on the researcher's judgement or operational convenience. The non-probabilistic method is based on random $\mathrm{C} \& \mathrm{D}$ waste piles choice, in which small C\&D waste samples are extracted.

Although non-probabilistic methods do not account for the whole population, they proved to be sufficient to support managers in the decisionmaking process. This research used the following steps to sample and determine the composition of C\&D waste destined to final disposal areas:

- $\quad 1^{\text {st }}$ step: Select at least 5 C\&D waste piles from different origins (renovations, new constructions, landscaping, demolition and public cleansing) and $5 \mathrm{~m}^{3}$ of C\&D waste destined to the sanitary landfill;

- $\quad 2^{\text {nd }}$ step: Select at least 3 C\&D waste piles from different origins (renovations, new constructions, and demolition) and $5 \mathrm{~m}^{3}$ of $\mathrm{C} \& \mathrm{D}$ waste destined to the $\mathrm{C} \& \mathrm{D}$ waste recycling plants;

- $\quad 3^{\text {rd }}$ step: Collect six random 18-liter samples from each container or mount;

- $4^{\text {th }}$ step: Join the 18 -liter samples in a single 108-liter sample, according to each origin;

- $5^{\text {th }}$ step: Select manually and visually the materials which compose the sampled C\&D waste;

- $6^{\text {th }}$ step: Measure mass and volume of the segregated materials;

- $7^{\text {th }}$ step: Agregate the results of the two groups on recycling plant charaterization (C\&D cement - predominance of cement materials such as concrete and grout; and mixed C\&D - predominance of ceramic materials, soil and small fractions of concrete and grout) and ponder considering the destined amounts of those materials, as shown in Equation 4.

$C_{\text {recyleplant-methodI }}=\frac{Q_{\text {cement }} . C_{\text {cement }}+Q_{\text {mixed }} C_{\text {mixed }}}{100}$

$\mathrm{C}_{\text {recycleplant-method } 1}(\%)$ : final composition percentage of recycle plant method 1;

$\mathrm{C}_{\text {cement }}(\%)$ : percentage composition of the material classified as "C\&D cement";

$\mathrm{C}_{\text {mixed }}(\%)$ : percentage composition of the material classified as "C\&D mixed";

$\mathrm{Q}_{\text {cement }}(\%)$ : percentage composition of the material quantified as "C\&D cement";

$\mathrm{Q}_{\text {mixed }}(\%)$ : percentage composition of the material quantified as "C\&D mixed".

- $8^{\text {th }}$ step: Agregate results of the three groups on landfill characterization (new constructions and renovations, demolition and public cleansing) and ponder considering the destined amounts of those materials, as shown in Equation 5.

$C_{\text {landfill-methodI }}=\frac{Q_{\text {const }} \cdot C_{c o n s t}+Q_{e w} \cdot C_{e w}+Q_{c a} \cdot C_{c a}}{100}$

$\mathrm{C}_{\text {landfill - method 1 }}(\%)$ : final composition percentage of landfill - method 1; $\mathrm{C}_{\text {const }}(\%)$ : percentage composition of the material originating in construction, renovation, repair or demolition;

$\mathrm{C}_{\mathrm{ew}}(\%)$ : percentage composition of the material originating in earthwork; 
$\mathrm{C}_{\mathrm{ca}}(\%)$ : percentage composition of the material originating in $\mathrm{C} \& \mathrm{D}$ cleaning areas;

$\mathrm{Q}_{\text {constr }}(\%)$ : percentage composition of quantified C \& D originating in construction, renovation, repair or demolition;

$\mathrm{Q}_{\mathrm{ew}}(\%)$ : percentage composition of quantified C \& D originating in earthwork;

$\mathrm{Q}_{\mathrm{ca}}(\%)$ : percentage composition of quantified C \& D originating in C\&D cleaning areas.

For the procedure of the second method, photographs of C\&D waste piles $\left(5 \mathrm{~m}^{3} \mathrm{each}\right)$ were taken in three stages, as shown in Figure 3. Six pictures for each pile were collected representing three sections, as recommended by NBR 10.007 for piles sampling — base, middle and face. This method used the same C\&D waste piles sampled in the first method.

The images were then analyzed through the AutoCAD ${ }^{\circledR}$. This software contributed to complement the manual separation of the components, dividing them per areas, which were calculated to estimate the percentage of each component. Figure 4 presents the components divided per areas with the software's support. Finally, the samples were characterized by the arithmetic mean of the results of base, middle and face characterization.
In both methods, the quantitative characteristics of the sampling group and sites were weighed for a better representation, resembling equations 4 and 5 .

Based on the results of the characterization in the recycling plant and in the transfer area, the arithmetic mean was calculated for both methods, in order to obtain the representative characterization for each area.

To conclude the qualitative characterization by C\&D waste volume, the results from the recycling plant and transfer station were compilated depending on the weighing by the quantity assigned to each area. In order to compilate these results, Equation 6 was used.

$C_{C \ll D}=\frac{Q_{\text {recyclingplant }} \cdot \bar{C}_{m_{\text {recelingplant }}}+Q_{\text {landfil }} \cdot \bar{C}_{\text {mlandfill }}}{100}$

$\mathrm{C}_{c \& D}$ (\%): final composition percentage of municipality C\&D waste;

$\mathrm{C}_{\text {recycle plant }}(\%)$ : arithmetic mean of both methods for C\&D waste samples from the recycling plant;

$\mathrm{C}_{\text {landfill }}(\%)$ : arithmetic mean of both methods for C\&D waste samples from the C\&D waste landfill;

$\mathrm{Q}_{\text {recycling plant }}(\%)$ : weighted mean of the mean percentage composition of C\&D waste quantified at the recycling plant;

$\mathrm{Q}_{\text {landfill }}(\%)$ : weighted mean of the mean percentage composition of $\mathrm{C} \& \mathrm{D}$ waste quantified at the $\mathrm{C} \& \mathrm{D}$ waste landfill.

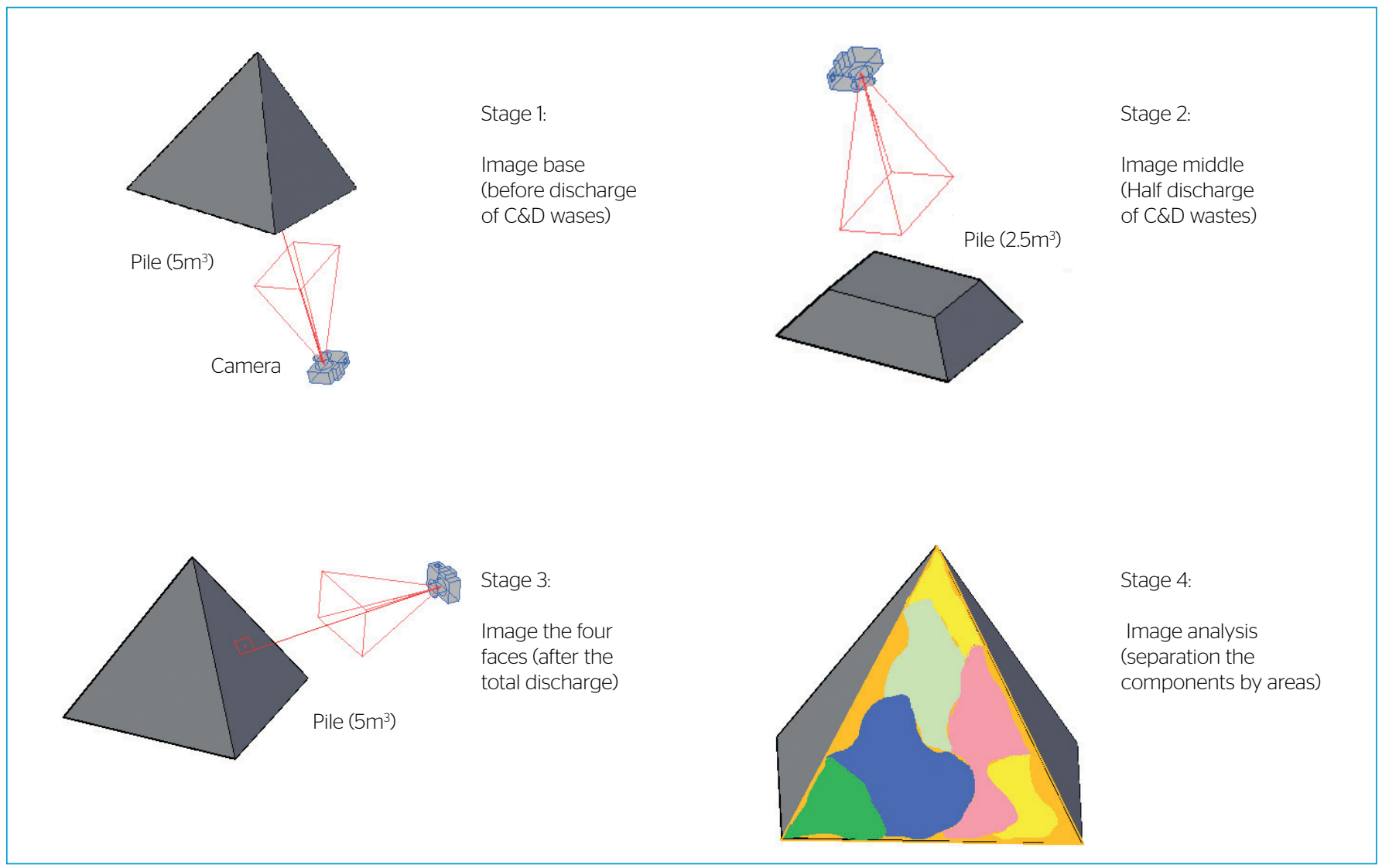

Figure 3 - Qualitative characterization of construction and demolition (C\&D) waste samples by image analysis. 


\section{RESULTS AND DISCUSSION}

\section{Results and discussion of the first stage}

This study analysed data from the authors' researches in 2003, 2009 and 2015/2016 - analyzed period: September, 2015 to August, 2016. Results show that the first indicator allowed estimating daily C\&D waste generation ranging from 95.93 to $184.83 \mathrm{~m}^{3} /$ day (Table 2). The second one estimated a generation ranging from 654.94 to $678.43 \mathrm{~m}^{3} /$ day (Table 3 ) and the last ranging from $572.03-592.52$ to $239.42 \mathrm{~m}^{3} /$ day (Table 4).

The first indicator was not the most appropriate one to estimate waste generation in the municipality, because it did not quantify the $C \& D$ waste generated in reforms, demolitions, public cleaning services and unapproved constructions. Therefore, this indicator's results depend on other information. The second indicator was not appropriate to quantify C\&D waste generation, for it was not based on reliable information, such as the transportation company's control documents. Finally, the third method proved to be more appropriate to estimate waste generation in a municipality, as it was obtained by the tracking and receipt control of waste transport in recycling and final disposal areas (Table 5). It is necessary to inform that the third method did not account for illegal discharge dumping sites; it only quantified C\&D waste collected by public cleaning services.

The comparison between 2003 and 2009 indicates a 10.6\% increase of C\&D waste generation for new constructions. However, between 2009 and 2015/2016, there was a 60\% generation reduction, justified by the fall of the licensed areas for construction. Also, the recycling C\&D waste tax almost tripled in the same period. This large reduction of C\&D waste discharges in the landfill and increased recycling tax can also be explained by the change of the management system. Before this period, the landfill was public and had no cost for disposal, but now its management is carried out by a private company. The management company increased the waste input control and prioritizes the recycling of the materials in its plant.

The first indicator proved to be necessary to verify the evolution of formal buildings in the municipality. However, differences obtained between the first and third indicators show the generation of waste from unapproved construction and demolition. In the 2015/2016 period, it is possible to observe a reduction on informal constructions, due to Brazil's economic crisis (Table 5). Unlicensed buildings are small and belong to people with less financial resources. The comparison of these indicators is of fundamental importance to understand and extend control measures and waste reduction programs.

Therefore, the last indicator allowed to estimate a C\&D waste daily generation of $239.42 \mathrm{~m}^{3}$ (287 t) in São Carlos, São Paulo, which represents a bulk rate of $1.22 \mathrm{~kg} /$ inhab.day, considering a population of 235,096 inhabitants (SEADE, 2016). The indexes of per capita generation are next to the lower limit of the generation presented by Pinto (1999) and Marques Neto (2005) - per capita generation from 1 to $3 \mathrm{~kg} /$ inhab.day. Per capita generation decrease from 3.0 to $1.22 \mathrm{~kg} /$ inhab.day may be due to a general decrease of the construction sector, as the first indicator inferred.

Table 2 - Construction and demolition (C\&D) waste generation estimated based on approved constructions areas (first indicator $-\mathrm{i}_{1}$ ).

\begin{tabular}{l|c|c|c} 
Reference & $\begin{array}{c}\text { Generation } \\
\left(\mathrm{m}^{3} / \mathrm{day}\right) \\
(2003)\end{array}$ & $\begin{array}{c}\text { Generation } \\
\left(\mathrm{m}^{3} / \mathrm{day}\right) \\
(2009)\end{array}$ & $\begin{array}{c}\text { Generation } \\
\left(\mathrm{m}^{3} / \mathrm{day}\right) \\
(2015 / 2016)\end{array}$ \\
\hline $\begin{array}{l}\text { C\&D waste generation in new } \\
\text { approved construction areas }\end{array}$ & $95.93^{\mathrm{a}}$ & $184.83^{\mathrm{b}}$ & $104.58^{\mathrm{c}}$ \\
\hline Total & 95.93 & 184.83 & 104.58 \\
\hline
\end{tabular}

aapproved construction areas equal $241.959 .95 \mathrm{~m}^{2}$ and bulk rate of $C \& D 137.02 \mathrm{~kg} / \mathrm{m}^{2}$; bapproved construction areas equal 466,192.98 $\mathrm{m}^{2}$ and bulk rate of C\&D $137.02 \mathrm{~kg} / \mathrm{m}^{2}$; capproved construction areas equal $263,767.19 \mathrm{~m}^{2}$ and bulk rate of C\&D $137.02 \mathrm{~kg} / \mathrm{m}^{2}$.

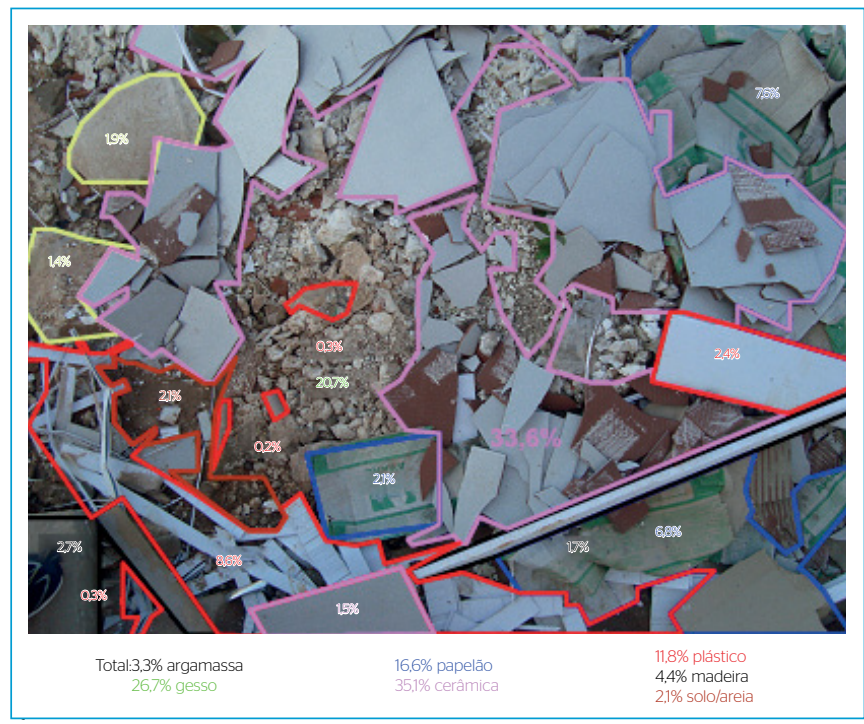

Figure 4 - Construction and demolition (C\&D) waste divided per common areas.

Table 3 - Estimation of the cargo transported by collectors (second indicator $-i_{2}$ ).

\begin{tabular}{l|c|c|c} 
Reference & $\begin{array}{c}\text { Generation } \\
\left(\mathrm{m}^{3} / \mathrm{day}\right) \\
(2003)\end{array}$ & $\begin{array}{c}\text { Generation } \\
\left(\mathrm{m}^{3} / \mathrm{day}\right) \\
(2009)\end{array}$ & $\begin{array}{c}\text { Generation } \\
\left(\mathrm{m}^{3} / \mathrm{day}\right) \\
(2015 / 2016)\end{array}$ \\
\hline $\begin{array}{l}\text { C\&D waste collected by } \\
\text { transport companies }\end{array}$ & 451.58 & 498.00 & - \\
\hline $\begin{array}{l}\text { C\&D waste collected by } \\
\text { excavation companies }\end{array}$ & 18.75 & 37.50 & - \\
\hline $\begin{array}{l}\text { C\&D waste collected by } \\
\text { private companies }\end{array}$ & 138.77 & 76.29 & - \\
\hline $\begin{array}{l}\text { C\&D waste collected by small } \\
\text { collectors }\end{array}$ & 69.83 & 43.15 & - \\
\hline Total & 678.43 & 654.94 & - \\
\hline
\end{tabular}

C\&D: construction and demolition; avalue obtained by interviews; bvalue obtained by receipt control at final disposal areas. 


\section{Results and discussion of the second stage}

Table 6 shows C\&D waste physical characterization results. We can observe that soil and sand are first in percentage per weight, with $33.14 \%$; ceramic compounds in second, with $23.96 \%$; and concrete and grout are the third and fourth, representing together $23,87 \%$.

Table 4 - Estimation based on tracking and receipt control of recycling and final disposal areas (third indicator $-\mathrm{i}_{3}$ ).

\begin{tabular}{l|c|c|c} 
Reference & $\begin{array}{c}\text { Generation } \\
\left(\mathrm{m}^{3} / \mathrm{day}\right) \\
(2003)\end{array}$ & $\begin{array}{c}\text { Generation } \\
\left(\mathrm{m}^{3} / \mathrm{day}\right) \\
(2009)\end{array}$ & $\begin{array}{c}\text { Generation } \\
\left(\mathrm{m}^{3} / \mathrm{day}\right) \\
(2015 / 2016)\end{array}$ \\
\hline $\begin{array}{l}\text { Discharge in transfer and } \\
\text { separation station and C\&D } \\
\text { waste landfills }\end{array}$ & 572.03 & 500.29 & 78.29 \\
\hline $\begin{array}{l}\text { Discharge in C\&D waste } \\
\text { recycling planta }\end{array}$ & - & 52.23 & 141.13 \\
\hline $\begin{array}{l}\text { C\&D waste discharge in } \\
\text { sanitary landfills }\end{array}$ & - & 40.00 & 20.00 \\
\hline Total & 572.03 & 592.52 & 239.42 \\
\hline
\end{tabular}

C\&D: construction and demolition; avalue obtained by receipt control at final disposal areas.

Table 5 - Estimated construction and demolition (C\&D) waste generation by demolitions and unapproved constructions.

\begin{tabular}{l|c|c|c} 
& 2003 & 2009 & $2015 / 2016$ \\
\hline First indicator $-i_{1}$ & 95.93 & 184.83 & 104.58 \\
\hline Third indicator $-i_{3}$ & 572.03 & 592.52 & 239.42 \\
\hline $\begin{array}{l}\text { Estimate demolition } / \\
\text { unapproved construction }\end{array}$ & 476.1 & 407.69 & 134.84 \\
\hline
\end{tabular}

Based on the results shown in Table 6 , approximately $81 \%$ of the total waste volume can be classified according to the Brazilian classification as "Class A" C\&D waste - recyclable in C\&D waste plants.

Based on the statistical comparison of method 1 and method 2 results (Table 7 ), which presented regularity, we observe that, of the C\&D waste sampled on the C\&D Waste Landfill, concrete (8.29), wood (5.83), ceramic (5.56), and grout (5.51) presented more data dispersion by standard deviation. The higher method dispersion observed for these elements is due to the fact that they present high-volume parts (wood and concrete beams, ceramic blocks with grout pieces).

For C\&D waste collected at the Recycling Plant, the highest data dispersion occurred for sand/soil (13.85), ceramic (13.41) and concrete (4.04). Unlike the samples from the Landfill, samples did not present high dirpersion for wood in this case, since it was separated before going to the plant. Nevertheless, concrete and ceramic blocks kept the same data dispersion tendency as in the landfill.

An evaluation of the classification methods showed that the first method proved to be more appropriate for samples with small volume parts, such as sand, stone and soil. However, this method is inefficient in representing samples with high volume compounds as beams, columns and concrete slabs. The second method is better than the first for the characterization of samples with high volume parts. However, this method is limited to represent characterizations that contain residues which might cover other C\&D waste,

Table 6 - Construction and demolition (C\&D) waste qualitative characterization in São Carlos, SP.

\begin{tabular}{|c|c|c|c|c|c|c|c|c|}
\hline \multirow[b]{2}{*}{ Component } & \multirow{2}{*}{$\begin{array}{l}\text { Recyclable in } \\
\text { C\&D waste } \\
\text { plants }\end{array}$} & \multicolumn{3}{|c|}{ C\&D Waste Landfill } & \multicolumn{3}{|c|}{ Recycling Plant } & \multirow{2}{*}{$\frac{\text { Total }^{1}}{(\%)}$} \\
\hline & & $\begin{array}{l}\text { Method } 1 \\
(\%)\end{array}$ & $\begin{array}{l}\text { Method } 2 \\
\text { (\%) }\end{array}$ & $\begin{array}{c}\text { Arithmetic } \\
\text { mean (\%) }\end{array}$ & $\begin{array}{l}\text { Method } 1 \\
(\%)\end{array}$ & $\begin{array}{l}\text { Method } 2 \\
(\%)\end{array}$ & $\begin{array}{c}\text { Arithmetic } \\
\text { mean (\%) }\end{array}$ & \\
\hline Concrete & recyclable & 19.40 & 7.68 & 13.54 & 16.14 & 10.43 & 13.28 & 13.52 \\
\hline Sand / Soil & recyclable & 31.26 & 32.58 & 31.92 & 55.56 & 35.97 & 45.77 & 33.14 \\
\hline Grout & recyclable & 6.47 & 14.26 & 10.37 & 11.09 & 9.38 & 10.24 & 10.35 \\
\hline Ceramic & recyclable & 28.15 & 20.29 & 24.22 & 11.80 & 30.77 & 21.28 & 23.96 \\
\hline Stone & recyclable & 2.64 & 0.02 & 1.33 & 1.33 & 1.77 & 1.55 & 1.35 \\
\hline Asbestos & non recyclable & - & - & - & - & 1.44 & 0.72 & 0.06 \\
\hline Asphalt & non recyclable & 0.13 & - & 0.07 & - & - & - & 0.06 \\
\hline Plastic & non recyclable & 1.12 & 2.64 & 1.88 & 0.29 & 0.24 & 0.27 & 1.74 \\
\hline Paper/Cardboard & non recyclable & 6.12 & 9.25 & 7.69 & 2.53 & 5.27 & 3.90 & 7.35 \\
\hline Metal & non recyclable & 0.18 & 1.79 & 0.98 & - & 0.04 & 0.02 & 0.90 \\
\hline Wood & non recyclable & 2.79 & 11.03 & 6.91 & 1.26 & 4.68 & 2.97 & 6.56 \\
\hline Gypsum & non recyclable & 0.89 & 0.03 & 0.46 & - & - & - & 0.42 \\
\hline Other $^{\mathrm{a}}$ & non recyclable & 0.85 & 0.43 & 0.64 & - & - & - & 0.58 \\
\hline Total & & 100 & 100 & 100 & 100 & 100 & 100 & 100 \\
\hline
\end{tabular}

aWaste classified as unserviceable (rubbers, brushes, rags and organic matter); bweight used in Equation 1 for the $C \& D$ waste landfill $\left(Q_{\text {landifl }}=92.1 \%\right)$ and the recycling plant $\left(\mathrm{Q}_{\text {recycing plant }}=8.8 \%\right)$, based on the quantitative survey. 
for example, plastic sheeting, cardboard and packaging. Therefore, mixing these two qualitative methods is more appropriate, since they complement each other.

Neither Pinto (1989) nor Marques Neto (2003) qualitative characterization methods consider infrastructure constructions in the characterization reckoning.

Characterizations are necessary and depend on historical, political and economic aspects, progress of construction technology, easy access to raw materials, changes on the $\mathrm{C} \& \mathrm{D}$ waste management system,

Table 7 - Comparative statistical verification of method 1 and method 2.

\begin{tabular}{l|c|c|c|c}
\multirow{2}{*}{ Component } & \multicolumn{2}{|c|}{ C\&D Waste Landfill } & \multicolumn{2}{c}{ Recycling Plant } \\
\cline { 2 - 5 } Concrete & $\begin{array}{c}\text { Arithmetic } \\
\text { mean (\%) }\end{array}$ & $\begin{array}{c}\text { Standard } \\
\text { deviation }\end{array}$ & $\begin{array}{c}\text { Arithmetic } \\
\text { mean (\%) }\end{array}$ & $\begin{array}{c}\text { Standard } \\
\text { deviation }\end{array}$ \\
\hline Sand / Soil & 13.54 & 8.29 & 13.28 & 4.04 \\
\hline Grout & 31.92 & 0.93 & 45.77 & 13.85 \\
\hline Ceramic & 10.37 & 5.51 & 10.24 & 1.21 \\
\hline Stone & 24.22 & 5.56 & 21.28 & 13.41 \\
\hline Asbestos & 1.33 & 1.85 & 1.55 & 0.31 \\
\hline Asphalt & - & - & 0.72 & 1.02 \\
\hline Plastic & 0.07 & 0.09 & - & - \\
\hline Paper/Cardboard & 7.68 & 1.07 & 0.27 & 0.04 \\
\hline Metal & 0.98 & 1.14 & 0.02 & 0.03 \\
\hline Wood & 6.91 & 5.83 & 2.97 & 2.42 \\
\hline Gypsum & 0.46 & 0.61 & - & - \\
\hline Other & 0.64 & 0.3 & - & - \\
\hline Total & 100 & - & 100 & - \\
\hline
\end{tabular}

C\&D: construction and demolition. surveillance, population growth, urban expansion, educational level, habits and customs.

Table 8 compares results from the physical characterization by Pinto (1989) and Marques Neto (2003), in a situation where infrastructure construction soils obtained in similar proportion on qualitative characterization were not considered. Pinto (1989) observed that concrete and grout are first in percentage per weight with $69.7 \%$ and ceramic compounds are in second with $29 \%$. Marques Neto (2003) estimated that ceramic compounds are first in percentage per weight with $50.5 \%$, and concrete/grout come in second with $33 \%$. The results of the characterization carried out by this study demonstrated a trend of concrete and ceramic greater generation, where both represent approximately $36 \%$. However, when compared with other characterizations there is a significant increase from 1.24 to $13.88 \%$ in the amount of waste from packaging (plastics, cardboard and paper). The estimated data indicates that $73 \%$ of generated C\&D waste can be classified as "Class A" waste, therefore recyclable in C\&D waste plants - sand, soil and stone were not considered.

\section{CONCLUSIONS}

Among the three indicators for $C \& D$ waste generation estimation, the third one proved to be more effective for the diagnostic used on management models. The first indicator can indirectly measure the evolution of the construction industry in the study area. The first indicator associated with the third may also give the manager an estimate of waste generation in unapproved constructions. The second indicator was not appropriate to quantify C\&D waste because it was not based on reliable information. The use of the second

Table 8 - Composition of construction and demolition (C\&D) waste in characterization studies.

\begin{tabular}{|c|c|c|c|c|}
\hline Component & $\begin{array}{c}\text { Recyclable } \\
\text { in C\&D waste plants }\end{array}$ & $\begin{array}{l}\text { Percentage per weight } \\
\text { (São Carlos-SP - 1989)' } \\
\text { (\%) }\end{array}$ & $\begin{array}{c}\text { Percentage per weight } \\
\text { (São Carlos-SP-2003) } \\
\text { (\%) }\end{array}$ & $\begin{array}{l}\text { Percentage by volume } \\
\text { (São Carlos-SP-2009) } \\
(\%)\end{array}$ \\
\hline Sand/Soil/Stone & recyclable & uncounted & uncounted & uncounted \\
\hline Concrete/ Grout & recyclable & 69.76 & 33.64 & 36.44 \\
\hline Ceramic Components & recyclable & 29.54 & 50.38 & 36.58 \\
\hline Finishing Materials & non recyclable & 0.20 & 1.63 & 0.89 \\
\hline Wood & non recyclable & 0.11 & 8.76 & 10.02 \\
\hline Paper / Cardboard / Plastic & non recyclable & - & 1.24 & 13.88 \\
\hline Asphalt & non recyclable & - & - & 0.09 \\
\hline Metal & non recyclable & - & 1.94 & 1.37 \\
\hline Asbestos & non recyclable & 0.39 & 2.41 & 0.09 \\
\hline Gypsum & non recyclable & - & 0.86 & 0.64 \\
\hline Totals & - & 100 & 100 & 100 \\
\hline
\end{tabular}

Source: 'Pinto (1989); ${ }^{2}$ Castro et al. (1997); ${ }^{3}$ Marques Neto (2003), adapted by the authors 
indicator would be recommended if there were corroborative waste transportation control documents. Finnally, the third indicator also proved to be more appropriate to estimate generation in municipalities which have implemented an integrated management system of C\&D waste. This method allowed estimating a daily generation of $239.42 \mathrm{~m}^{3}$ of C\&D waste, which represents a bulk rate of $1.22 \mathrm{~kg} /$ inhab.day, considering a population of 235,096 inhabitants.

About the study's second stage, the method for $C \& D$ waste qualitative characterization through image analysis proved to be efficient for the characterization of samples with high-volume parts, such as beams, columns and concrete slabs. However, this method is inefficient to represent characterizations that contain residues which might cover the other C\&D waste types, for example, plastic sheeting, cardboard and packaging. From these limitations, it is recomended that these materials should be homogenized or taken away from the piles in order to guarantee a representative characterization.

This method of image analysis is suitable for use in early diagnostics, which require fast results on $C \& D$ waste composition. However, its application in an interactive software is recommended for future works, associated with the use of technologies as drones and satelites. This method's evolution may contribute for large C\&D waste volumes, or even debris characterization in urban areas.
Based on the results of C\&D waste qualitative characterization, we can observe that approximately $81 \%$ of the total C\&D waste volume has potential to be recycled in C\&D waste recycling plants. The estimated data indicates that $73 \%$ of generated C\&D waste can be classified as recyclable, not considering sand, soil and stone. Comparison with previous classifications found an evolution of the existing constructive characteristics in the municipality with the presence of packaging (plastics, cardboard and paper).

\section{ACKNOWLEDGEMENTS}

The authors would like to acknowledge the São Paulo Research Foundation and the National Council of Research (CNPq) and Financer of Studies and Projects - BR (FINEP) for the financial support provided to this work.

\section{FINANCIAL SOURCE}

Brazilian National Council for Scientific and Technological Development (Conselho Nacional de Desenvolvimento Científico e Tecnológico - CNPq), Funding Authority for Studies and Projects (Financiadora de Estudos e Projetos - FINEP).

\section{REFERENCES}

ANGULO, S.C.; JOHN, V.M. (2006) Requisitos para a execução de aterros de resíduos de construção e demolição. Boletim Técnico da Escola Politécnica da USP, Departamento de Engenharia de Construção Civil; BT/PCC/436. São Paulo: EPUSP.

ARAÚJO, S.M.V.G. (2013) O desafio da aplicação da lei dos resíduos sólidos. Estudo. Consultora Legislativa da Câmara dos Deputados: Área XI Meio Ambiente e Direito Ambiental, Desenvolvimento Urbano e Regional. Brasília: Câmara dos Deputados. 32 p.

ASSOCIAÇÃO BRASILEIRA DE EMPRESAS DE LIMPEZA PÚBLICA E RESÍDUOS ESPECIAIS (ABRELPE). (2017) Panorama dos resíduos sólidos no Brasil 2016. São Paulo: Abrelpe.

ASSOCIAÇÃO BRASILEIRA DE NORMAS TÉCNICAS. (2004) ABNT NBR 1007 Amostragem de resíduos sólidos. Rio de Janeiro, 21d.

BIO INTELLIGENCE SERVICE. (2011) Gestão de Resíduos de Construção e Demolição na EU - Final report. Europa: European Commision (DG ENV).
BRASIL. (2002) Resolution no 307 - C\&D waste management. Brasília: Conselho Nacional do Meio Ambiente.

(2010) Law no 12,305, de 2 de agosto de 2010. National Policy of Solid Wastes. Diário Oficial da União, Brasília.

CÂMARA BRASILEIRA DA INSÚTRIA DA CONSTRUÇÃO (CBIC) Banco de dados - PIB Brasil e Construção Civil. Available at: <http:// www.cbicdados.com.br/menu/pib-e-investimento/pib-brasil-e construcao-civil>. Access on: August 2016.

CARMO, D.S.; MAIA, N.S.; CÉSAR, C.G. (2012) Evaluation of the typology of construction waste delivered to processing plants in Belo Horizonte, Brazil. Engenharia Sanitária Ambiental, v.17, n.2. http://dx.doi.org/10.1590/S1413-41522012000200008

CARNEIRO, F.P. (2005) Diagnóstico e ações da atual situação dos residuos de construção e demolição na cidade do Recife. 131 f. Dissertation (Mastering in Engenharia Urbana) - Universidade Federal da Paraíba, João Pessoa. 
CASTRO, M.C.A.A; SCHALCH, V; FERNANDES JUNIOR, J.L.; LEITE, W.C.A. (1997) Caracterização física e granulométrica dos entulhos gerados na construção civil na cidade de São Paulo. In: CONGRESSO BRASILEIRO DE ENGENHARIA SANITARIA E AMBIENTAL, 19., 1997, Foz do Iguaçu. Anais... p. 1667-1673.

CÓRDOBA, R.E. (2014) Estudo do potencial de contaminação de lixiviados gerados em aterros de resíduos da construção civil por meio de simulações em colunas de lixiviação. 340f. Thesis (Doctoring in Engenharia Hidráulica e Saneamento) - Escola de Engenharia de São Carlos, Universidade de São Paulo, São Carlos.

COSTA, R. V. G. (2012) Taxa de geração de resíduos da construção civil em edificações na cidade de João Pessoa. Dissetation (Mastering in Engenharia Urbana e Ambiental) - Centro de Tecnologia. Universidade Federal da Paraíba, João Pessoa.

DING, Z:; WANG, Y:; ZOU, P.X. (2016) An agent based environmental impact assessment of building demolition waste management: Conventional versus green management. Journal of Cleaner Production, v. 133, p. 1136-1153. https://dx.doi.org/10.1016/j. jclepro.2016.06.054

EUROSTAT. (2010) Waste statistics: tables and figures. Luxembourg: Publications Office of the European Union.

FERGUSON, D.W.; MALE, J.W. (1980) The water pollution potential from demolition waste disposal, Journal of Environmental Science and Health. Part A: Environmental Science and Engineering, v. 15, n. 6, p. 545-559. https://doi. org/10.1080/10934528009374949

GODOY, M.B.R.B. (2013) Dificuldades para aplicar a Lei da Polítca Nacional de Resíduos Sólidos no Brasil. Caderno de Geografia, v. 23, n. 39, p. 1-12.

HOORNWEG, D.; BHADA-TATA, P. (2012) What a waste: a global review of solid waste management. Washington, D.C.: World Bank Group. 98 p. (Urban Development Series Knowledge Papers).

INSTITUTO BRASILEIRO DE GEOGRAFIA E ESTATISTICA (IBGE). (2008) National Research of Sanitation 2008. Brasilia: Brazilian Institute of Geography and Statistics.

(2010) São Carlos. IBGE Cidades. Brasília: Brazilian Institute of Geography and Statistics.

(2014) Pesquisa Anual da Indústria da Construção. Brasilia: Brazilian Institute of Geography and Statistics.

INSTITUTO DE PESQUISA ECONOMMICA APLICADA (IPEA). (2012) Diagnóstico dos Resíduos Sólidos da Construção Civil. Relatório de Pesquisa. Brasília: Instituto de Pesquisa Econômica Aplicada. $42 \mathrm{p}$.

JACOBI, P.R.; BESEN, G.R. (2011) Gestão de resíduos sólidos em São Paulo: desafios da sustentabilidade. Estudos Avançados, São Paulo, v. 25, n. 71, p. 135-158. http://dx.doi.org/10.1590/SO10340142011000100010
KATZ, A:; BAUM, H. (2011) A novel methodology to estimate the evolution of construction waste in construction sites. Waste Management, v. 31, n. 2, p. 353-358. https://doi.org/10.1016/j. wasman.2010.01.008

KofowoRola, O.F;; Gheewala, S.H. (2009) Estimation of construction waste generation and management in Thailand. Waste Management, v. 29, n. 2, p. 731-738. https://doi.org/10.1016/j. wasman.2008.07.004

LIMA, A.S.; CABRAL, A.E.B. (2013) Characterization and classification of construction waste in Fortaleza (CE). Engenharia Sanitária Ambiental, v. 18, n. 2. http://dx.doi.org/101590/S141341522013000200009

Llatas, C. (2011) A model for quantifying construction waste in projects according to the European waste list. Waste Management, v. 31, n. 6, p. 1261-1276. https://doi.org/10.1016/j. wasman.2011.01.023

LU, W.; WEBSTER, C; PENG, Y; CHEN, X:; ZHANG, X. (2O17) Estimating and calibrating the amount of building-related construction and demolition waste in urban China. International Journal of Construction Management, v. 17, n. 1, p. 13-24. https://doi.org/10.1080 /15623599.2016.1166548

Mañà I Reixach, F; Sagrera I Cuscó, A.; Gonzàlez I Barroso, J.M. (2000) Base de datos BEDEC. Available at: <http://www.tec.es/ nouBedec.e/bedec.aspx>. Accessed on: June 26, 2016.

MARQUES NETO, J.C. (2003) Diagnostic Study for Management of Construction and Demolition Waste of São Carlos-SP. Dissertation (Mastering) - São Carlos School of Engineering, Universidade de São Paulo, São Carlos.

(2005) Gestão dos resíduos de construção e demolição no Brasil. São Carlos: Editora RiMa. 162 p.

(2009) Estudo da gestão municipal dos residuos de construção e demolição na bacia hidrográfica do Turvo Grande (UGRHI-15). $629 \mathrm{f}$. Thesis (Doctoring in Ciências da Engenharia Ambiental) - Escola de Engenharia de São Carlos, Universidade de São Paulo, São Carlos.

MESJASZ-LECH, A. (2014) Municipal waste management in context of sustainable urban development. Procedia-Social and Behavioral Sciences, v. 151, p. 244-256. https://doi.org/10.1016/j. sbspro.2014.10.023

Pinto, T.P. (1989) Perda de materiais em processos construtivos tradicinais. São Carlos: Departamento de Engenharia Civil da UfSCar.

(1999) Differentiated methodology for solid waste management of urban construction. Thesis (Doctoral) - Polytechnic School, Universidade of São Paulo, São Paulo.

ROUSSAT, N.; MÉHU, J.; ABDELGHAFOUR, M.; BRULA, P. (2008) Leaching behavior of hazardous demolition waste. Waste Management, v. 28, n. 11, p. 2032-2040. https://doi.org/10.1016/j. wasman.2007.10.019 
SECRETARIA ESTADUAL DE PLANEJAMENTO E ECONOMIA (SEADE). Projeções populacionais. Dados. Available at: <http://www. seade.gov.br>. Accessed on: Aug., 2016.

SENG, B.; KANEKO, H.; HIRAYAMA, K.; KATAYAMA-HIRAYAMA, K. (2011) Municipal solid waste management in Phnom Penh, capital city of Cambodia. Waste Management \& Research, v. 29, n. 5 , p. 491-500. https://doi.org/10.1177/0734242X10380994

SISTEMA NACIONAL DE INFORMAÇÕES SOBRE SANEAMENTO (SNIS). (2O14) Diagnóstico do manejo de resíduos sólidos urbanos 2014. 13. ed. Brasília: SNIS. 154 p.

Solís-Guzmán, J.; Marrero, M.; Montes-Delgado, M.V.; Ramírezde-Arellano, A. (2009) A Spanish model for quantification and management of construction waste. Waste Management, v. 29, n. 9, p. 2542-2548. https://doi.org/10.1016/j.wasman.2009.05.009

Tam, V.W.Y (2008) On the effectiveness in implementing (a waste management-plan method in previous construction. Waste Management, v. 28, n. 6, p. 1072-1080. https://doi.org/10.1016/j. wasman.2007.04.007

THE WORLD BANK. Brasil: aspectos gerais. Available at: <http:// www.worldbank.org/pt/country/brazil/overview\#1>. Access on: Aug. 2016.
TOWNSEND, T.G.; JANG, Y.; THURN, L.G. (1999) Simulation of construction and demolition waste leachate. Journal of Environmental Engineering, v. 125, n. 11. https://doi.org/10.1061/ (ASCE)0733-9372(1999)125:11(1071)

UNITED STATES ENVIRONMENTAL PROTECTION AGENCY (USEPA). (2013) Advancing Sustainable Materials Management. Washington, D.C.: USEPA.

Villoria Sáez, P.; Del Río Merino, M. (2010) Gestión de residuos de construcción y demolición (RCD) en obras de edificación. Buenas prácticas en albañilería. In: VILLORIA SÁEZ, P.; DEL RÍO MERINO, M. Proceedings of the I Congreso nacional de investigación aplicada a la gestión de la edificación (CO/GE). Alicante: Universidad de Alicante. p. 1003-1027.

Villoria-Sáez,P.; Del Río Merino,M.; Porras-Amores, C.(2011)Estimation of construction and demolition waste volume generation in new residential buildings in Spain. Waste Management \& Research, v. 30, n. 2, p. 137-146. https://doi.org/10.1177/0734242X11423955

ZAMBRANA-VASQUEZ, D.; ZABALZA-BRIBIÁN, I.; JÁÑEZ, A. ARANDA-USÓN, A. (2016) Analysis of the environmental performance of life-cycle building waste management strategies in tertiary buildings. Journal of Cleaner Production, v. 130, p. 143-154. http://dx.doi.org/10.1016/j.jclepro.2016.02.048 